\begin{tabular}{|c|c|}
\hline $\begin{array}{c}\text { ÇÜTAD } \\
\text { Çukurova Üniversitesi } \\
\text { Türkoloji Araştırmaları Dergisi }\end{array}$ & $\begin{array}{l}\text { Cilt 6, Sayı } 2 \\
\text { Aralık } 2021\end{array}$ \\
\hline $\begin{array}{l}\text { ISSN: 2587-1900 } \\
\text { E-ISSN: 2548-0979 }\end{array}$ & $\begin{array}{l}\text { Geliş Tarihi: } 23.03 .2021 \\
\text { Kabul Tarihi: } 24.09 .2021\end{array}$ \\
\hline \multicolumn{2}{|c|}{$\begin{array}{l}\text { Makale Künyesi (Derleme): Aydoğan, B. (2021). Gazetelerin arka } \\
\text { sayfalarından başlayarak Türkçede kendine yer açan yabancı bir } \\
\text { sözcük: cool. Çukurova Üniversitesi Türkoloji Araştırmaları Dergisi } \\
6(2), 970-988 \text {. }\end{array}$} \\
\hline \multicolumn{2}{|c|}{ https://doi.org/10.32321/cutad.901803 } \\
\hline
\end{tabular}

\title{
GAZETELERIN ARKA SAYFALARINDAN BAŞLAYARAK TÜRKÇEDE KENDINE YER AÇAN YABANCI BİR SÖZCÜK: COOL
}

\section{ÖZET}

\section{Bedri AYDOĞAN ${ }^{1}$}

Diller arasında etkileşim ve karşılıklı alışverişler olması mümkün ve doğaldır. Türkçe de tarih boyunca çeşitli dillerle etkileşime girmiş sözcükler almış ve vermiştir. Türkçe önceleri Arapça ve Farsçadan, Tanzimat'tan sonra Fransızca etkisinde kalarak oradan sözcükler almıştır. 1970'lerden sonra ise İngilizce sözcükler Türkçeye girmeye başlamış ve giderek yoğunlaşmıştır. İngilizce sözcükler kimi zaman ihtiyaçtan kimi zaman çaresizlikten kimi zaman da özenti nedeniyle Türkçeye girmiş ve dilimizi baskı altına almıştır. Bu konuda çeşitli yakınmalar elbette olmuş, Türkçe lehine çabalar gösterilmiş, karşı çıkışlar olmuştur. Bu yazıda bu sözcüklerden biri olan cool sözcüğü ele alınmıştır. Cool gazetelerin arka sayfalarından başlayarak dilde yaygınlık kazanmış ve reklamlara kadar girmiştir. Bizce cool bir ihtiyaçtan değil daha çok özentiden dilde kendine yer bulmuştur. $\mathrm{Bu}$ yazı, bu durumu kanıtlamak ve Türkçede cool yerine pek çok sözcüğün olduğunu ortaya koymak amacıyla yazılmıştır.

Anahtar kelimeler: Cool, İngilizce sözcükler, dilde yozlaşma.

\section{A LOANWORD THAT MAKES A PLACE IN TURKISH, BEGINNING FROM THE BACK PAGES OF NEWSPAPERS: COOL}

\begin{abstract}
Interaction and exchange between languages is possible and natural. Throughout history, Turkish has interacted with various languages and has given and received words. Turkish first took words from Arabic and Persian, and after the Tanzimat, influenced by French. After the 1970s, English words started to enter Turkish and
\end{abstract}

1 Çukurova Üniversitesi, Fen-Edebiyat Fakültesi, Türk Dili ve Edebiyatı Bölümü, Dr. Öğr. Üyesi. bedriaydogan01@gmail.com https://orcid.org/0000-0002-5450-551X 
ÇÜTAD Gazetelerin Arka Sayfalarından Başlayarak Türkçede Aralık 2021 Kendine Yer Açan Yabancı Bir Sözcük: Cool

\begin{abstract}
became more intense. English words sometimes entered Turkish because of need, sometimes despair, sometimes because of wannabe and put our language under pressure. Of course, there were various complaints about this issue, efforts were made in favor of Turkish, and there were objections. In this article, the word of cool, which is one of these words, is discussed. Theword of cool,starting from the back pages of newspapers, has become widespread in the language and enteredadvertisements. In our opinion, cool has found a place in the language rather than a need, rather than a wannabe. This article was written to prove this situation and to reveal that there are many words instead of cool in Turkish.
\end{abstract}

Keywords: Cool, English words, corruption in language.

\title{
Gíris
}

Dillerin birbirinden sözcük alması ve vermesi bir dil yasasıdır. Bu yasaya göre her dil birbirinden sözcük alabilir ve verebilir. Bu alışverişte bir denge ve makullük olduğu sürece sorun yoktur. Makullük sınırı bir dil aleyhine aşıldığında sorun başlar. Lehte olan diller ya da dili kullananlar kendi adına isterlerse elbette övünebilirler. Baskın kültürler ve onu ifade eden diller, özellikle son yıllarda İngilizce diğer dillere sözcük vermektedirler. Bazen de sözcükler kimi dilleri kullananlar tarafından alınmaktadırlar. Bunda kolaycılığın, özentinin, yetersizliğin, çaresizliğin ve taklitçi olmanın da etkisi vardır. Türkçenin bu açıdan sicili eskiden beri bozuktur.

Sicilimizi bozan öykünmecilik ve başka nedenlerle son yirmi-otuz yılda, İngilizcenin olumsuz etkisi yaşanmakta, yabancı yeni sözcükler Türkçeye girmektedir. Pek çok kişinin yakınmasına ve duyarlık yaratma çabalarına karşı, "ama bunun da karşılığını bulamadık" biçiminde cümleleri sık sık duymaktayız. Bu sözcüklerden biri de "cool"dur². Bu sözcük daha çok gazete eklerinde, magazin sayfalarında yer almaktayken giderek başka özellikteki sayfalara yayıldı. Kimi yazarlar hoşlanıp sevdiklerinden kimileri olanaksızlıktan bu sözcüğü benimsediler. Sözcüğü olanaksızlık nedeniyle kullandığını söyleyen İclal Aydın şöyle diyor:

“Türkçe karşılığını bulamadık gitti 'cool' sözcüğünün. 'Serin' desek değil, 'serinkanlı' desek yakın ama o da değil. Ayrıca sözlükte 'klas', 'harika', 'sakin', 'uzak' ve 'küstah' gibi karşılıkları da var ama hiçbiri sözcüğün orijinalindeki anlam dünyasını kuşatamıyor bence.

\footnotetext{
${ }^{2}$ Cool sözcüğünün "o"ları uzun u ve "l"si kalın olarak seslendirilmektedir. Biz de yazımızda doğal olarak bu kurala uyduğumuzdan ekleri kalın sıradan getirdik. Alıntılarda yazı sahipleri nasıl kullanmışlarsa onu koruduk.
} 
Biz de bu yüzden “cool' sözcüğünü kullanıp duruyoruz, ağzımıza yakışmasa bile" (10 Eylül 2006). ${ }^{3}$

Biz bu görüşe katılmadığımızı hemen belirttikten sonra sözcüğün anlamına ve kullanım biçimlerine bakmak isteriz. İngilizcede hem isim, hem sıfat, hem belirteç hem de fiil olarak kullanılan cool sözcügünün anlamlarını Redhouse'tan alıntılayalım:

Cool (kul): s. serin, oldukça soğuk (hava); serin tutan (elbise); sakin, kayıtsız, soğukkanlı kendine hakim; A.B.D., k. dili hakikî; argo iyi, mükemmel; güz. san. Mavi ve yeşil tonlarının hakim olduğu. Cool-headed s. Serinkanl, heyecana kapılmayan. Coolish s. serince. Coolly z. kayıtsızca, tasalanmaksızın.

Cool (kul) i. Serinlik; argo sükûnet, soğukkanlılık. He blew his cool. argo soğukkanlılığını kaybetti.

Cool (kul) f. serinletmek, serinlemek, soğutmak, soğumak, teskin etmek, sükûnet bulmak. Cool it! argo Sakin ol! Cool of, cool down sükûnet bulmak, öfkesi geçmek. Cool one's heels bekleme odasında beklemek (Redhouse, 1986, 210).

İsim olarak kullanıldığında serinlik, soğukkanlılık; sıfat olarak kullanıldığında serin, sakin, soğukkanlı, kayıtsı;; fiil olarak kullanıldığında ise soğumak, soğutmak, serinlemek, serinletmek, sakinleşmek, sakinleştirmek, yatışmak, yatıştırmak; bazı sözcüklerle birlikte kullanıldığında da kurnaz, pişkin anlamlarına gelmektedir.

$\mathrm{Bu}$ yazıda cool sözcüğünün temel anlamı ve diğer anlamları üzerinde durup, örnekler aracılığıyla (ya da son zamanlarda yaygınlık kazanan bir sözcükle örnekler üzerinden) farklı anlamlarını belirleyeceğiz. Sözcük Türkçede temel anlamıyla daha az, kullanıcıların yüklediği başka anlamlarıyla daha sık kullanılmaktadır.

\section{Cool Sözcüğünün Temel Anlamlarında Kullanılışı}

$\mathrm{Bu}$ sözcüğe roman ve öykü yazarlarından Buket Uzuner'in $\mathrm{Su}$ romanında da rastladım. Buket Uzuner sözcüğ̈̈ temel anlamlarıyla kullanmış.

- Bak biraz efsanevi olacak ama hani sigaraya, içkiye gerek duymayan 'cool' tipler vardır ya, gerçekten vardır böyle dingin, sakin,

\footnotetext{
${ }^{3}$ İclal Aydın'ın bu yazısını kopyalayıp kayıtlarıma almışım. Yazının tarihi de belli, ancak nerede yayımlandığını bulamadım. İclal Aydın on bir yıl Vatan Gazetesinde köşe yazmıştır. Muhtemelen bu gazetede çıkmış olmalı, ancak gazetenin arşivine ulaşamadım. Bir sayfalık 250 sözcüklük bu yazıda cool sözcüğü on kez geçiyor, yazı coola ve Ajda Pekkan'nın coolluğuna ayrılmış.
} 
hafif çekingen gibi görünen ama çocukluktan beri acayip özgüvenli, belki çok sevilerek, pohpohlanarak büyümüşlerdir de çöplükte bile sultan gibi gezinirler hani... İnsan gicık olur bunlara... Biz burada sakinleşmek için neler yapıyoruz, tipe bak doğuştan zeki, güvenilir, karizmatik falan... (Uzuner, 2013, s.50)

Buket Uzuner "cool tip"i açıklarken sözcügün bizdeki tüm anlamlarını ve kullanılışını bir bir saymış. Buna göre temel anlamı sakin, dingindir. Ardından bizde yaygın kullanılan diğer anlamlarını eklemiş. Bunlar da özgüvenli, zeki, güvenilir ve karizmatiktir. Zeki ve güvenilir olma özgüvene yol açıyor ya da onu pekiştiriyor. En sonunda karizmatik anlamını ekliyor. Bunun halk dilindeki karşılığı ise havalı. Buket Uzuner sözcügün temel ve yaygın kullanılış anlamlarının tamamını bu alıntıda toplamıştır.

- Demir senin çok 'cool' olduğunu söyledi. 'Kıskandığını bile belli etmez’ dedi (Hürriyet Cumartesi, 13 Nisan 2013).

Duygularını gizleme açısından soğukkanlılığı, sakinliği, ketumluğu anlatıyor. Burada da sözcüğün temel anlamına yakın kullanılmış. nasil?

- Eşiniz röportajlarında hiç konuşmayan cool bir adam. Evde

- Evde de az ve öz konuşur. Çok konuşan kiși benim (Hürriyet Cumartesi, Duman Solisti Kaan Tangöze ve eşi ile Söyleşi, 10 Kasım 2012).

Buradaki cool soğukkanlı, durgun, dingin, sakin anlamlarına denk düşüyor.

- Güler gibi pimpirikli değilim; çok rahat ve cool'ümdür. Hatta kızım bana kızar "Ne kadar rahatsın" diye (Sabah, Günaydın, 2 Mayıs 2015, Aydan Şener'le söyleşi).

Doğrudan anlamı rahat olarak verilmiş, ama rahatı güçlendirmek için cool eklenmiş. Bu eklenti sakin, soğukkanlı, geniş anlamlarını taşıyor.

- Bak şimdi mesela Burcu'yu arıyorum... Onun da çocuğu var ama 'cool' bi insan hayatını allak bullak etmiyor öyle! (Hürriyet Kelebek, 19 Ocak 2014, Ece'nin Maceraları, Çizgi Roman Karikatür)!

Cool, rahat, geniş, sakin, endişesiz, paniksiz anlamlarında.

- Sürekli bir iniş çıkış hali yani. Çünkü biz tam da buyuz: Enerjimiz çok sibelcanayzır. En coolumuzun içinde bile bir tutam var (Hürriyet Kelebek, 1 Mayıs 2016, Onur Baştürk). 
Sibel Can'ın repertuvarını ve onun kişisel enerjisini değerlendiriyor. İnişli çıkışlı bir hal. Sibel Can'ın bu hali rahatlı̆̆ı, kendini kasmayışı anlatıyor. Cool sözcügüne de rahat anlamını yüklüyor.

- Bizimki acayip cool (Hürriyet, 3 Aralık 2013, Ayşe Arman).

Ayşe Arman, cool'u sakin, rahat, soğukkanlı anlamlarında kullanmış. Kızı Alya'ya Fındıkıran Balesinde rol teklif edildiğindeki sakinliğini anlatırken sözcügü temel anlamında kullanıyor.

Cool'un doğrudan ve dolaylı anlamını vermeye çalışanlar ve verdikleri anlamlar ile cool'un dolaylı ve doğrudan anlamlarını bulduğumuz örnekler:

Daha önce İclal Aydın'dan örneklediğimiz gibi coolun anlamı üzerinde düşünenler ve kendilerine göre anlam vermeye çalışanlar var. Ayşe Arman coolun yanına yıldız koyarak yazı sonunda anlamını havalı olarak açıklar. Burada cool, bir kenti nitelemek için kullanılmış. İnsanlar için kullanıldığı gibi nesneler ve mekânlar (kentler, lokantalar, oteller) için de kullanılmakta.

- Acaba kadınların cool yani serin duruşlu erkekleri beğenmelerinin ardında, akıllı spermin serin havayı sevmesinin etkisi var mıdır (Hürriyet, 27 Eylül 2014, Ertuğrul Özkök)...

- Zaten ailenin şöhret ve sansasyon seven çocuğu. Babaya düşkün. Belki de bu yüzden hep yaşı büyük, babacan, kendisini şefkatle sevip kollayan, yol gösteren, yer gösteren erkeklerle birlikte olmuş. Adam hayatı boyunca zeki ve yaratıcı, bu yüzden ukala ve herkesi küçümseyen, fazla cool. Belli ki karısından ve hastalığından da bunalmış, sıkılmış (Posta, 3 Temmuz 2011,Yazgülü Aldoğan).

Cool sözü politik yazı yazan Yazgülü Aldoğan'ın sözlügüne de girmiş. Politik yazılarında da güncel başka özellikteki yazılarında da görülüyor. Yazgülü Aldoğan da dolaylı olarak coola anlam vermiş. Cool, ukala ve herkesi küçümseyen, daha doğrusu akıl, zeka ve yaratıcılığından kaynaklanan özgüvenli anlamındadır.

- 'Eşim için canımı veririm'

Çılgın bir hayran kitlesi olan ve gayet 'cool' bulunan bir erkek, Cansel Elçin (40). Erişilmezliği sadece bir görüntü. Marie Claire Dergisi'nin röportaj yaptığı yakışıklı oyuncu, kısa süre önce evlendiği eşi Pınar'a "Hayatımın kadını" diyor (Posta, 13 Ekim 2012).

Cool bulunan bir erkek denilirken ne kastedildiği net değilse de karizmatik, beğenilen anlamlarını verebiliriz. Konuşan kişi bu anlamları dışında bir anlama daha işaret ediyor, o da erişilmez. Böylece coola erişilmez anlamı da veriliyor. 
- Uğur Acar'ın yüzünün artık oturduğunu, eskisinden daha iyi göründüğünü belirten Baykal, "Karizma bir duruşu var. Gençler 'cool' tabirini kullanıyorlar. 'Cool' bir duruşun var. Basında görüntülerden izlediğimden daha iyi gördüm. Böyle bir nakil yaşadığını düşünmek zorunda değiliz. Şu an pekala nakil yaşamamış, soğukkanlı davranan, her şeye fazla yüz vermeyen, karizmatik şahsiyet duruşu içerisinde. Müthiş başarı" diye konuştu (Posta, 26 Mart 2012, Deniz Baykal).

Antalyalı siyasetçi Deniz Baykal yüz nakli konusunda konuşuyor. Konuşmasında siyasetçiliğini ve hatipliğini konuşturan Baykal, hemşerilerine, kentine mesaj verirken gençleri ve onların dilini unutmuyor. Coola bir karşılık veriyor: Karizma duruş, karizmatik. Ayrıca coolun diğer temel karşılıklarını da buna ekliyor: Soğukkanlı, her şeye yüz vermeyen.

\section{- Hep böyle güleryüzlü müydün?}

Oynadığımı düşünsene ne kadar zor olurdu. Oynayabilseydim cool adamı oynardım ama hem kliplerde hem sokakta gördügünüz adam, aynı adam. Gülümsemeyi ve kahkahayı dostlarımla paylaşmayı seviyorum (Posta, 20 Ekim 2012).

Söyleşi yapılan kişi neşeli ve paylaşmayı seven karakterini anlatıp ve cool olamayacağını söylerken bu sözcüğe anlam veriyor. Neşeli olmayan, gülümsemeyen. Dolayısıyla cool, ciddi, soğuk, içine kapalı, sert, donuk anlamlarına geliyor.

“cool”, Hülya Avşar'ın tabiriyle "cool ukala”, Acun Ilıcalı'nın görüşüyle "kendisine güvenli" birisi. Böyle olmasının da başarısında payı büyük elbet (Posta, 22 Şubat 2011).

$\mathrm{Bu}$ alıntıdan Hülya Avşar'ın da coola bir anlam verdiğini anliyoruz. Bunu coola bir eklemeyle yapar. Buna göre cool, ukala (akıllı) anlamındadır. Tabii ki olumsuz bir anlam ve alay yok. Kendine güvenen anlamında. Avşar'a Acun da eklenmiş, ona göre de cool özgüvenlidir.

- Senin yaptığın müzik Anadolu rock mu?

Aslında değil ama çok cool olmayışım, insanlara samimi yaklaşmam nedeniyle beni Anadolu insanı gibi algılıyorlar ve yaptığım müziği de Anadolu rock olarak görüyorlar (Hürriyet Kelebek, 17 Mayıs 2025, Umut Kuzeyle söyleşi).

Cool, samimi olmanın karșılığı olarak anlamlandırılmıș. Bununla soğuk olmadığı, cana yakın olduğu söyleniyor. Cool (soğuk ve mesafeli) değilim, samimi ve cana yakınım. 


\section{Cool Sözcüğünün Farklı Anlamlarda Kullanılışı}

- Bir adet gülmeyen Ece Erken

Gülmemek yenilik midir, Gülmeyince cool mu olunur gibi detay kelebeklerin beynimde uçuşup durmasına an itibariyle şu haber son verdi (Hürriyet Kelebek, 05 Aralık 2013, Onur Baştürk).

Gülümsemenin karşıtı olmalı. O hâlde sert, soğuk anlamı verilmeli. Belki donuk. Oysa Ece Erken şeker kız yüzlü biriymiş. Yeni imajı ise şeker olmayan. Ciddi anlamı da verilebilir.

- Çünkü şimdiye kadar sanatçı ve eserini satın alan koleksiyonerleri böyle yan yana fotoğraflanmış olarak görmedik.

Nedenleri malum: Gerek yoktur, cool değildir, eser sanki sırf o kaleksiyoner için yapılmış, yani sipariş gibi görünür. (Hürriyet Kelebek, 6 Nisan 2013, Onur Baştürk)

Cool, cazibeli, çekici, karizmatik.

- Uğur Yücel'in Yeşil Kabare'sinde okuma provasındayız. Ben orda ögrenciyim, bir de patavatsızım ya, iyi bir şey diyeyim derken kötü bir şey söyleyip batmamak için kısa kısa cevaplar veriyorum. Ezik görünmeyeyim diye aşırı da cool davranıyorum! Kibir gibi algılanmış o. Bu yüzden Türkan Şoray başta bana gıcık olmuş. Tanıdıktan sonra çok sevdik birbirimizi ama (Hürriyet Kelebek, 29 Kasım 2012, Nurgül Yeşilçay'la söyleşi)...

Cool, kibir olarak algılandığına göre kibir değil. Peki Yeşilçay’ın coolluğu ne anlamda? Donuk mu? Soğuk mu? Özgüvenli mi? Mesafeli mi? Ezikliğin karşıtı olunca özgüvenli diye düşünmek gerek.

- Çağan Irmak 'Dedemin İnsanları' filminde aile hikâyesini anlatt1; onlar oynadi

\section{Başrollerde cool ve cooliye (başlik)}

Gökçe Bahadır da siz de dışarıdan çok cool gibi duruyorsunuz ama bir araya gelince bu hava değişmiş sanki

- Ben cool değil, çok çok cool'üm! Gökçe de cooliye (Gülüyor). Birlikte cool ve cooliye isimli bir dizi de oynayp sonra da sana röportaj vermeyeceğiz (Hürriyet Pazar, 27 Kasım 2011, Hakan Gence'nin röportaj1).

Röportaj okunduğunda cool ve cooliyeye net bir karşılık çıkmıyor. Göründüklerinden cool oldukları söyleniyor. Hemen yine ilk anlamlara gidiyoruz. Soğuk, sert, mesafeli, donuk, neşesiz mi? Farklı mı? Dışardan cool görünüyorlar, yakınlaşınca hava ne anlamda değişiyor. Sıcak, neşeli mi olmuşlar. Yoruma ihtiyaç var. 
- Facebook artık gençler için "cool” değil. (başlık)

Peki bu facebook hâlâ demode olmadı mı?

Gençler için artık cool değil. Çünkü hiçbiri, annesinin olduğu mecrada olmak istemiyor. Düşünsene, arkadaşlarına havalı gözükmek için bir fotoğraf yüklüyorsun, altına halan, teyzen, dayın "Maşallah evladım!" diye yorum yazıyor. Bu nedenle gençler daha "yeni”yi takip ediyor ve kullanıyor, Twitter, Vine vs. gibi (Hürriyet, 4 Nisan 2013, Ayşe Arman).

Burada cool yeni, moda anlamında kullanılmış. Cazip anlamını da verebiliriz. Ama ilk cümlede bunu anlamak mümkün değil. Anlamı haberin ya da yazının tamamını okuyarak çıkarabiliyoruz.

Hürriyet Cumartesi ekinde "Enerjisi Dans Pistinde" başlıklı bir haber ve yazı yer alıyor. Hürriyet'in düzenlediği bir parti ile ilgili haberde daha çok fotoğraf var. Bir karenin yanındaki şu cümlede cool geçiyor:

-“Önümüz arkamız sağımız solumuz sobe: Şehrin en cool tipleri, en asi tavırları, en aranan simaları ve en şı bohemleri bu partide."

Cümlede pek çok sıfat var. Cool dışında hepsini anlıyoruz, ama coola ne anlam vereceğimiz biraz sıkıntılı. Sifatın ilk anlamları olan soğuk, serin, donuk pek uygun düşmüyor. Belki yine en uygunu havalı olacak, ama başka karşılıklar da yakıştırılabilir.

- Ebru Öztürk birbirinden 'cool' ve şık kombinasyonlarıyla Instyle'a poz verdi (Akşam, 7 Ekim 2012).

Coolun hangi anlamda kullanıldığı belli değil. Çekici mi, cazip mi, rahat mi, havalı $\mathrm{m}$ ?

\section{Yardımcı Fiillerle Kullanımları: Deyim Yerine ya da Deyim Gibi Kullanmak}

Cool davranmak: Sakin durmak, sakin olmak, heyecan göstermemek.

- Ondan etkilenip etkilenmediğiniz

Bir erkek, bir kadınla tanıştıktan sonraki ilk 20 saniye içinde onun kendisinden etkilenip etkilenmediğini anlıyor. İstediğiniz kadar cool davranın, istediğiniz kadar ilgisiz görünün, tanışma seromonileri konusunda istediğiniz kadar tecrübeli olun, karşı cins beden dilini okumayı bilen biriyse hislerinizi anında çözüyor (Posta, 13 Ekim 2011).

Cool dur(ma)mak: 
-21 bin çocuk ve gencin okuma alışkanlıkları üzerinde yapılan araştırmada internet ve bilgisayar oyunlarına artan ilgi nedeniyle kitap okuma oranında ciddi bir düşüş olduğu ortaya çıktı. Gençler özellikle elinde kitapla gezmenin "cool” durmadığını düşündüklerini söyledi (Posta, 7 Ekim 2012).

Sözcük bir tamlama içinde, bir deyim gibi kullanılmış. Yakışmamak, şık durmamak, moda olmamak ya da daha yerinde söyleyişle demode olmak anlamlarına gelmektedir.

\section{Cool görünmek:}

- Tişört ve bluzlar - Her zaman her yere

Hem gündüz hem gece rahat ve cool görünen tişört ve bluzlar en dikkat çekici parçalardandır. Göğüs ölçülerinize uyum modelleri seçerseniz hata yapmazsınız (Posta, 25 Eylül 2012).

Cool görünmek, şık olmak, şık durmak, anlamında kullanılmış.

Cool hisset(tir)mek: Sakin olmak, rahat olmak.

- Siz "biz uyurken” evlendiniz. O gün nasıl geçti? Ve şimdi ne değişti? Ve neler hâlâ aynı?

T.Ü: Evet, Türkiye'de herkes uyurken biz evlendik. 10 saatlik zaman farkı var aramızda... O gün komikti, heyecanlıydık ancak aynı zamanda garip bir şekilde cool hissediyorduk. Sabah doktor randevumuz vardı. İki saat sonra düğünümüz olduğunu öğrenince doktorumuz da şaşırdı (Posta, 25 Ocak 2011, Tuba Ünsal'la söyleşi).

Coola burada anlam vermek biraz zor gibi. Heyecanlıydık aynı zamanda cool hissediyorduk denildiğine göre sakin, soğukkanlı anlamı verilebilir. Heyecanlının zıttı.

- Bunlar sizi cool hissettirecektir (Hürriyet Pazar, 29 Kasım 2015, Sibel Arna'nın söyleşisi).

Cool tarafı olmak: Ciddi, sakin yanı olmak.

- Hem çocuksu taraflarım vardır benim, hem çok hassasımdır, hem çok komik ve şirinimdir hem çok cool taraflarım vardır. Daha bir sürü kadını içimde barındırıyorum. Bu oyunculuğum için avantaj. Hepsi olabilirim (Pazar Vatan, 24 Ağustos 2009, Beril Özcan'ın Aydan Şener'le söyleşisi).

Konuşan pek çok özelliğine coolu eklemiş, ama anlamı net değil. Hassas, çocuksu, komik, şirin dışında bir yanını söylemek istiyor, ama ne?

Cool tavır yapmak: Sakin görünmek, sakin kalmak. 
- Bir kısım vatandaş "askerin yatak odasına da girildi, artık her şey bitti, bulunan belgeleri yarın tarafta okuruz" diye hayıflanmada. Bir kısım vatandaş da "Yargıya, hukuka güvenin, suç işleyen, yargıya hesap verecek! diye şıkır şıkır oynadığı belli olmasın diye cool tavır yapmakta (Posta, 29 Aralık 2009, Yazgülü Aldoğan).

Rahat, sakin, heyecana, sevince kapılmayan anlamlarında kullanılmış.

Cool tavrı (tavır) takınmak: Sakin olmak, ilgisiz kalmak, takmamak.

Haklısınız da, Ayşe, kendi çevresinden bir genç adamla evlenseydi, kimsenin umrunda olmaz, Başbakanın CHP'ye takındığı cool tavrı takınır, "Meclise gelmiyorlarsa gelmesinler, çok da fifi, nolmuş yani?” derdi. Ama şimdi öyle mi? İhanet, aşk, ihtiras, terk, vicdan, ne isterseniz var bu Ali Taran- Ayşe Özyılmazel hikayesinde (Posta, 3 Temmuz 2011,Yazgülü Aldoğan).

\section{Cool duruş:}

Rahatlığı ve cool duruşu bana benziyor olabilir (Hürriyet Pazar,15 Eylül 2013, Çağatay Ulusoy'la söyleşi).

Sakin ve rahat anlamında. Cool temel anlamında kullanılmış.

\section{Cool ile Birlikte Kullanılan Sözcük: seksi, seksi ve cool}

Özellikle kadınlar seksi ve cool olmak istiyorlar. Sonuçta hepimizin jean giydiğinde aynaya dönüp ilk baktığımız yer belli! Dolayısıyla mükemmel oturması gerekiyor. Kadınların seksi olmakla beraber cool görünmesi önemli. Bu arada popoyu kaldırmak için, beli ince göstermek için bazı kalıp hileleri olduğunu da Ebru'dan öğreniyoruz (Posta, 28 Kasım 2009).

Buradaki cool sanırım çekici, çarpıcı anlamında kullanılmış. Seksilik de var. Seksi sıfatını pekiştirmek için kullanılmış.

Cool sözcüğü ve Ajda Pekkan: Cool olarak anılan kadın.

Cool sözcüğü ülkemizde Ajda Pekkan'la birlikte kullanılmıştır denilebilir. İlk kez Ajda Pekkan için cool kadın nitelemesi yapılmıştır. Ajda Pekkan için böyle nitelemede bulunulması onun 2006 yılında Cool Kadın adlı bir albüm yapmasından kaynaklanıyor. Aynı adı taşıyan şarkının sözlerini Sezen Aksu yazmış. Coolun geçtiği bölüm şöyle:

Ne kadar çok sevgim vardı

Bir o kadar da endișem gösteremedim

Ben aslında gördüğün o cool kadın değildim 
Buradaki cool rahat, sakin, özgüvenli anlamları taşıyor. İlk kullanışta temel anlamını yansıtmış sözcük. Sevgisini, endişesini saklamış, özgüvenli davranıp gerçek duygularını yansıtacak kadar sakin, soğukkanlı olamamış. Bundan dolayı hayıflanıp yakınıyor.

- Neyse, beni asıl ilgilendiren, bir kadının 'cool' olması. Hele bu bizimle aynı topraklarda yetişmiş bir Havva kızıysa insanı daha da şaşırtıyor. Bizde kadının 'cool' olması kolay değildir çünkü. Kadına biçilen rol daha çok 'kul' olmaktır. Ajda Pekkan'ın kadınlar tarafından bu kadar çok sevilmesinin nedeni de buradadır belki; kadınlara 'kul' olmaktan çıkıp 'cool' olmaya giden yolu göstermiştir Ajda Pekkan. Hem de yıllar önce.

'Kadınlar tarafindan da sevilen kadın' olmak, yıldızlar aleminde hiç de kolay değildir. Ajda Pekkan olmak, Müjde Ar olmak, Sezen Aksu olmak gerekir (10 Eylül 2006, İclal Aydın).

- Kovalar cool ve güzel insanlardır. (...) Bizden de bir örnek verelim, Ajda Pekkan (Posta, 14 Aralık 2010, Yazı, Çağdaş Ertuna).

Görülüyor ki cool olmak Ajda Pekkan'la özdeşleşmiş. Cool sözcügünü Türkiye'ye getiren ayrıca cool olmayı beceren, coolluğun timsali olarak görülen bir kadın. Kadınlara cool olmayı ögretmesiyle önemsenmiş. Onunla ilgili olarak yapılan işlerde coolluğu vurgulanmış. Coolluğu başarıyla temsil ettiğine kesinlikle inanılıyor. Reklamlarda bu özelliği vurgulanıyor.

\section{Cool Erkekler:}

Cool sıfatı öncelikle insanlar için kullanılmaktadır. Cool kadınlar ve kızlar olduğu gibi cool erkekler de vardır. Coolluk kadın ve kızlar için daha sık kullanıldığından erkeklerin cool olması daha önem kazanmaktadır. Cool görünen erkeklerden biri Berk Oktay'mış. Manken ve oyuncu olan erkek için şöyle bir haber başlığı atılmış: 2015)

- Şehrin en cool erkeği: Berk Oktay (Hürriyet Follow, 14 Kasım

Bir başka haber de ise "En cool baba" belirlenmiş. Bu, Barselona'daki Sonar Festivalinde sırtında oğlunu gezdiren babadır.

Sonar'ın en cool babası oğlu ile festivalin ilgi odağı oldu (Sabah Günaydın, 19 Haziran 2016).

Cool sıfatı erkekler ve babalar için daha takdirkâr bir anlamda kullanılmaktadır. $\mathrm{Bu}$ alıntılar gösteriyor ki cool bir değerlendirme ölçütüdür. Magazin sayfalarında bu tür ölçütler, buna göre yapılan değerlendirme ve seçimler de var.

\section{- Haftanın cool'u}


Ev sahibi Alpay; kendi davetinde deri elbisesi, tarzına uygun aksesuvar seçimi, topuğu metal Aperlai ayakkabısı, modern saç kesimi ve uygun makyajıyla haftanın en cool olanıydı (Sabah Günaydın, 10 Kasim 2013).

Böylelikle, moda - modaya uymayan (demode), beğendim beğenmedim, ş1k - rüküş, in - out gibi köşelere cool - cool olmayan köşesi de eklenmiş oluyor. Cool bu kadar moda olsa da zaman zaman coolluk bitti mi gibi tartışmalar da yapılıyor. İște bir örnek:

- Cool olmak out doğal olmak in.

Ayşe Özyılmazel köşesinde cool olma durumlarından bahsetmiş; neler cool neler değil bir bir maddelemiş, anlatmış.

- Ayşeciğim, artık cool olma durumu out! Hiçbirimiz karşımızdakine 'Ah tatlım, çok coolsun' tepkisi vermiyoruz. Dönem; doğal olma, rahatlama, hakiki olma dönemi. Evdeki halimiz var ya, kapılar ardındaki; işte o halimiz, en makbulü ve en tercih edileni. E doğal olan insanın en büyük özelliği; sevilmesi. Zaten en cool olma durumu da biraz itici sanki (Sabah Günaydın, 17 Mayıs 2015, Mert Vidinli).

İçinde sıkça cool geçen bir yazı parçası. Coolu bunca kullanmasına karşın coolluğun artık gözden düştügünü vurguluyor. Buraya göre coolluk yapay, donuk, ciddi, soğuk, içtenliksiz, gösterişe yer veren anlamlarına geliyor. Şimdi bunları terk etmek ve yerine karşıtlarını koymak dönemi imiş. Coolluk olumlu özelliklerini yitirmiş âdeta. $\mathrm{Bu}$ yüzden insanlara coolluktan vazgeçmeleri öğütleniyor neredeyse. Beş maddede neler yapmak gerektiğini belirliyor. Oysa insanlar nasıl cool olunur diye soruyorlardı internette, bilenlere. "Cool olmak” yazdığınızda karşınıza binlerce yanıt gelmektedir. Cool olmanın 12 kuralı, cool olmanın 41 yolu gibi önerilerle karşılaşılıyor. Okulda nasıl cool olunacağı da anlatılıyor. "Kıl olma cool ol" diye espriler yapılıp kula kulluk (coolluk) etmenin kötülüğünden söz eden şarkıya göndermede bulunuluyor. Hatta coolluğun kitabını yazmaktan söz ediliyor. Coolluk danışmanlığı diye bir meslek de varmış.

- Nasıl dünyanın en cool kadını olunur?

Chole Sevigny için ilk kez 'dünyanın en cool kadını' başlığı atıldığında henüz 19'undaydı, y1l 1994'tü, Kurt Cobain hırkasıyla sahnede son konserini veriyordu. Aradan neredeyse 21 yıl geçti. 90'lara dair her şey küf koktu, Sevigny 40'ında, zamana ve tüm akımlara karşı geliyor. Özenenlere yedi maddelik yol kılavuzu (Hürriyet Cumartesi, 20 Haziran 2015).

$\mathrm{Bu}$ alıntıda cool olmak için yedi öneri veriliyor. Önerilerin yediden kırka uzandığını yukarda söylemiştik. 
Haftanın coolu seçildiği gibi, yukardaki alıntıda olduğu gibi coolluk sembolleri de oluşuyor. Onlardan biri de Dylan Penn'miş.

- Cool'luk sembolü Dylan Penn

Neden? Dünyanın en cool ailelerinden birine sahip; babası Sean Penn, annesi Robin Wright. Sevgilileri de bir o kadar afili. Robert Pattinson'la anıld1, sonrasından da Steve Mc Queen'in torunu Steven'le birlikte olmaya başlandı (Hürriyet Cumartesi, 22 Şubat 2014).

Aslı Barış bu yazısında yeni tanrıçaları anlatıyor. Yeni tanrıçaların cool olması gerektiğini anlıyoruz böylece.

- Cool'luğun kitabını yeniden yazan kız.

Sadece iki senede rakiplerini geride bırakıp Prada, Dior, Chanel'in seçtiği isim oldu? Peki onu bu kadar özel ve 'cool' yapan ne? (Hürriyet Cumartesi, 27 Şubat 2016, Aslı Barış yazısı)

Cool'luğun kitabını yazan Lexi Boling'miş. Yazıya göre şunları yaparsanız coolsunuz: Kötülüğünüzü saklamayın / Arkadaşlarınızı da kötülerden seçin / Özür dilemeyin, haydi dilediniz o da yarım ağız olsun / Rejim mi o da nesi / spor yap ama / Başkalarının düşüncelerini umursamayın.

Bu tür yazı ve söyleşilerle coolluğun kitabı yazılıyor ve nasıl cool olunacağı anlatılmış oluyor. Söyleşi dışında da "Sizin için ne cool'dur" başlıklı yazılar yazlıyor. Bu yazılar başkalarından yapılan aktarmalarla açılıyor. Maksat coolluk üzerine bir söz açmak, yazıya girmek.

Yukardaki başlığı taşıyan yazı şöyle sürüyor:

Geçenlerde köşesinde 'İstanbul'da ilişkide cool olma durumu çiftlerin yeni takıntısı' diye yazmış ve çevresinde gözlemlediği 'cool olma' kurallarını sıralamış. Buna göre de coolluğun gerekleri şunlardır:

-Mesajlaşırken emoji kulanmamak / gelen mesajlara geç cevap vermek / Sevgiliyle buluşurken süslenip püslenmemek / Salaş ve umursamaz olmak / Sürekli meşgul görünmemek / Yoğunluktan şikayet etmemek / cool görünmeye kafayı takmamak / cool olmak için cool görünmeye çabalamamak.

Sonuç şuymuş: 'cool olmak' illa nasıl giyindiğin, ne müzik dinlediğin, ne yediğin, ne çeşit yoga yaptığın, ne kadar fit göründüğün, ne kadar yoğun olduğun demek değil. Bir başka deyişle gerçekten 'cool olmak' için her zaman 'cool görünmeniz' gerekmiyor. 
Nasıl olman gerektiğini sürekli dikte eden bir şekilde kendin olabilmeyi başarmak, bence en cool'u...

$\mathrm{Bu}$ alıntı, cool olmanın sanki herkesin yaşamını sardığı izlenimini yansitıyor. Buna göre herkesin işi cool olmaya çabalamak. Bu hâl ve bunu yansıtan dil yayılmış, etkili olmuş görünüyor.

\section{Katmerli Yabancılaşma, Coola Trend Eklemek}

\section{En cool ve en trend spor}

Kite sörf (uçurtma sörfü), uçurtmanın gücüyle suyun üstünde board yardımı alarak yapılan bir spor.

Ayağınızda board, elinizde uçurtma. Dolayısıyla da pek havalısınız. Ama bu seviyeye gelmek hiç de kolay değil (Pazar Vatan, 17 Ekim 2011).

\section{Coolun Kentler için Kullanılması: Cool kadın ve erkekler olur da cool kentler olmaz mi?}

Cool sıfatı kentler için de kullanılmaktadır. Türkiye'deki kentler içinde en cool olanı ise İstanbul olarak belirlenmiş. İstanbul'un coolluğu Ayşe Arman'ın bir söyleşisinde yer almaktadır. Arman, Los Anceles'te Eva Mendes'le bir söyleşi yapmış. İstanbul'u cool olarak niteleyen de Eva Mendes. İstanbul'a bir kez gelen Mendes, Los Anceles dişında İstanbul'a yaşabileceğini söylemiş ve İstanbul için "Gördüğüm en cool* şehir” demiş (Hürriyet Cumartesi, 23 Mart 2013, Söyleşi).

Görüldüğü gibi coolun yanında bir yıldız var. Yıldızlı notla coolun anlamı havalı olarak verilmiş. Cool, kentler için kullanıldığında büyülü anlamına da geliyor.

İstanbul için cool sıfatını Nil Karaibrahimgil "İstanbul ne zaman bu kadar cool oldu" başlıklı yazısında kullanmıştır. Yazının içinde de beş kez cool sıfatına yer verir. İki alıntı yapıyoruz:

- Ben İstanbul'un cool olduğunu, bayramda Berlin'de galerileri gezerken anladım.

Ben İstanbul'un cool olduğunu, babam NewYork'tayken telefonda 'kızım sen New York'tan bir şeyler istiyorsun ama İstanbul'dan aldığın kıyafetler gibisi burda yok' dediğinde anladım (Hürriyet, 5 Kasım 2012).

\section{- Cool ötesi}

İstanbul'da kültür ve sanat zamanı... Neden mi? İstancool 13 Haziran'da başlıyor. Dünyanın en cool isimleri de festival kapsamında şehre geliyor. Shirly Manson, Liya Kebede gelecek isimlerden sadece 
birkaçı. (..) "Tabii ki bu festival kaçmaz." Her şey bu denli cool olduğu noktada geriye söyleyecek söz kalmıyor.. (Sabah Cumartesi,7 Haziran 2014, Burcu Aldinç).

İstancool'le ilgili pek çok haber çıkarken etkili olduğunu söylediğimiz cool da seve seve sıklıkla kullanılıyor.

\section{İstanbul Dışında Başka Cool Yerler}

Türkiye'de başka bir cool yer de birçok özelliği ve mekânlarıyla Bodrum elbette. Orada çok cool hareketler yapmak mümkün.

- Bodrum’da sezonun en cool hareketi (Hürriyet Cumartesi, 28 Haziran 2014, Savaş Özbey).

Savaş Özbey yazısında Bodrum'da yapılacak cool etkinlikleri mekânlara bağlı olarak sıralamış. Bu örnektekine benzer başka mekânlardan da söz ediliyor. Böylece bir cool mekânlar listesi çıkıyor. Bu mekânlar öneriliyor, gidip görmeye özendiriliyor. Örnekler:

- Otelin de cool'ü makbul

Sırf Michel Berger Hotel'de kalmak için Berlin'e gidenler var. Tasarım harikası otelin misafirleri de benzer duygunun insanları.

Cool, yaratıc1, rahat (Hürriyet Pazar, 19 Ocak 2014)...

-Yılbașında ne yapacağız? Sorusu...

Bir sürü cool adres sıralanıyor. Kaz Dağlarındaki Adatepe köyünde yer alan İda blue, Kapadokya'daki Sacred House (Hürriyet Kelebek, 12 Aralık 2015, Onur Baştürk)...

Bunun yanında cool mekân önerileri ve sıralamaları yapılıyor. En cool on otel gibi, top on listeleri yapıliyor. En cool bar, en cool mini lokanta, en cool mimar. Görüldüğü gibi cool lokantayla cool mimar da yan yana getirilebiliyor. Cool sinır tanımıyor. Cool mimar cool mekânı yaratıyor. Bütün bunları Mert Vidinli'nin cool işler başlığı altında yazdıklarından okuyoruz. Bu yazıda da cool sözcügü sekiz kez kullanılmış.

Bir başka en tutulan beş restoran listesi Savaş Özbey tarafından yapılır. Bunlardan ikisi Unter ve Hacı Memiş'miş.

-Casuel atıştırma meraklılarına Unter: İstanbul için Karaköy neyse, Çeşme için Hacı Memiş o. Karaköy'ün en cool kafesi Unter de yazlık için Hacı Memiş’i seçti (Hürriyet Cumartes, 7 Haziran 2014).

Mekân için cool sözcüğü ziyadesiyle kullanılmıştır. Yukardaki örneklerde şık, pahalı, cool mekânlardan söz edilmiş, peki pazarların coolu olur mu? 
- 'Kentin cool pazarı yeni adresinde başlıklı haber' pazarların da coolu olacağını gösteriyor. Ancak Pazar sözcüğü ucuz olanı çağrıștırmasın. Coolun olduğu yerde bu mümkün değil. Pazarın adı bile bunu kantllyor: SOUG. Bu pazar Karaköy'de kurulurken Bomonti'ye taşınmış. Karaköy ve pazar ilk bakışta uygun düşüyor. Karaköy'de her şeyin pazarı var, ucuzu var, aranılan her şey orada bulunur, ama bunlar yanıltmamalı bizi. Burada Direct Message'ın bikini ve plak koleksiyonu, NYKS'in kahve ve bar koleksiyonunu bulabilirsiniz. Sonuçta kendine yakışan semte, Bomonti'ye taşınmış. Kısaca bu Pazar, o ucuz pazarlardan değil, sosyete pazarıdır. Cool pazardir.

\section{SONUÇ}

Sözcüklerin bir dile ilk girişi konusunda tespitte bulunmak kolay değildir, ancak yakın zamanda girenleri tespit edip izlemek daha kolay olabilir. "Cool”u da bu sinıfa sokabiliriz. Bizim tespitlerimize göre bu sözcügün yoğun olarak kullanılması 2010 yılında başlar. Bundan önce 2006'da sözlerini Sezen Aksu'nun yazdığı ve Ajda Pekkan'ın söylediği bir şarkıda geçer. Şarkının üçüncü dizesi "Ben aslında gördüğün o cool kadın değildim"dir. İlk kullanımını bilmesek de bu dizeyi erken kullanımlar içinde sayabiliriz. Ayrıca bu şarkıda cool sözcüğü temel anlamında kullanılmıştır.

Yazının başında verdiğimiz dizelerde Ajda Pekkan neden cool kadın olamadığını açıklar. Sevgisi, heyecanı vardır, ama cool kadın olamadığı için bunları gösterememiştir. Sevgisini, endişesini saklamış, özgüvenli davranıp gerçek duygularını yansıtacak kadar sakin, soğukkanlı olamamıştır.

İlk kullanımının ne zaman olduğunu tam bilmediğimizi belirtip, 2010'dan sonra kullanımının dikkat çekecek kadar sıklaştığını söylediğimiz sözcük kaynak dilde ad, sıfat ve fiil olarak kullanılmaktadır. Bizde de sözcük ad, sıfat ve fiil olarak kullanılmıştır. Sözcüğün temel anlamı ad, sıfat, fiilde de aynıdır. Sakin, soğukkanlı, serinlemiş. Örnekleri incelediğimizde sözcüğün bizde de serin sakin, soğukkanlı, sükûnet bulmuş olarak temel anlamında kullanıldığını görüyoruz.

Sözcük bizde anlam zenginleşmesine uğramış ve temel anlamı dışında daha sık kullanılmıştır. Sözcüğe anlam vermeye çalışan kullanıcılar olduğunu belirlemiştik. Sözcük yeni olduğu için anlamı tartışılmış, zaman zaman karşılık bulunmaya çalışılmış, ama İngilizcesi daha yeğ tutulmuştur. Kimileri bunu Türkçenin yetersizliğine bağlamıştır.

Ayşe Arman coolun yanına yıldız koyup, anlamını havalı olarak verir. Ertuğrul Özkök cool yani serin duruşlu diyerek ne anlamda 
kullandığını açıklar. Yazgülü Aldoğan, "ukala ve herkesi küçümseyen, fazla cool” cümlesinde coola ukala, herkesi küçümseyeni eklemiş, buna yakın bir anlam vermiş. Buna göre cool kendini beğenmiş, burnu büyük anlamına geliyor. Ayşe Arman bir başka yazısında coolu Eva Mendes'ten aktarmış. Eva Mendes, İstanbul için "Bugüne kadar gördügümm en cool şehir.” diyor. Bu cümlenin geçtiği kısmın başlığı ise "İstanbul Büyülü Şehir!” Havalı ve büyülü. Cool sözcügü havalı, büyülü anlamında kullanılmış. Kent için büyülü sıfatı elbette daha uygun, kentler değil, insanlar havalı olur.

Az önceki örnekte olduğu gibi cool, kentler ve mekânlar için de kullanılıyor. Bir internet gazetesi dünyanın en güzel 10 garını seçmiş: "Amerika merkezli internet gazetesi Huffington Post, geçenlerde dünyanın en havalı (İngilizce cool) 11 tren garını seçti." (Posta, 12 Ağustos 2012) Havalı anlamı verildikten sonra İngilizcede cool denildiği yazılmış, ama bu kullanım daha çok bize ait olmalı. Biz coola havalı anlamını yüklüyoruz.

Cool sözcüğünü sadece (genç sayılan) gazeteciler kullanmıyor. Siyasetçi Deniz Baykal, kendi kenti Antalya'da yapılan ilk yüz nakli için konuşuyor ve coolu kullanıyor. "Şu an pekala nakil yaşamamış, soğukkanlı davranan, her şeye fazla yüz vermeyen, karizmatik şahsiyet duruşu içerisinde." "Cool”un temel anlamına karizmatik eklemesini yapıyor. Böylece cool bizde yeni bir anlam kazanıyor. Bu anlam havalı anlamına yakın, âdeta onu pekiştiriyor.

Bir başka örnekte cool şu anlamı kazanıyor:

"Neşeli olmayan, gülümsemeyen." Dolayısıyla cool, ciddi, soğuk, içine kapalı, sert, donuk anlamlarına geliyor.

Burada temel anlamı kullanılmak isteniyor, ama neşeli olmayan, gülümsemeyen sözcükleri temel anlamla eşit ya da aynı değil. Dolayısıyla az da olsa farklı anlam kazanmış.

$\mathrm{Bu}$ sözcüğü çok kullananlardan Onur Baştürk de "Gülmemek yenilik midir, Gülmeyince cool mu olunur” diye soruyor. Cool ile gülümseme arasında ters bir orantı kurulmuş, ama bir emin olma hâli yok.

Hülya Avşar "cool ukala" biçiminde pekiştirmeli kullanıyor. Buna göre kendini beğenmiş, özgüvenli anlamı çıkabilir. Ben buna çok bilmiş anlamını da ekliyorum.

"Başrollerde cool ve cooliye” cümlesinde ise farklı bir kulanım var. Arapçadaki dişi ve erkek olma özelliği vurgulanmış, cool erkek, 
cooliye dişi. Sözcükle oynayarak anlatıma güç ve mizah katılmak istenmiş.

Cool sözcüğü tek başına kullanıldığı gibi cool erkek, cool kadın gibi tamlamalı olarak da kullanılıyor. Kent, lokanta örneklerinde de çoğunlukla tamlamalı olarak da kullanılmaktadır.

Cool sözcüğ̈̈ yardımcı fiiller alarak birleşik yapılar kurmaktadır. $\mathrm{Bu}$ yapıların bazısı deyim özelliği gösterir. Cool davranmak, Cool görünmek, Cool hisset(tir)mek, Cool dur(ma)mak, Cool tarafı olmak, Cool tavır yapmak, Cool tavrı (tavir) takınmak

Cool'la yan yana getirilen bir sözcük de seksidir. Seksi ve cool, cool ve seksi biçimlerinde kullanılmaktadır.

Coola trend eklenerek katmerli bir yabancılaşma yapılarak da kullanıldığı oluyor.

Moda sayfalarında in-out köşeleri yapılıp, haftanın inleri ve outları belirleniyor. İn out bazen moda-moda olmayan (demode) biçiminde Türkçeleştirilmiş. Bunun gibi cool-cool olmayan sütunları yapılmaya başlandı. Markaların cool olmak için insanların ne yapmaları gerektiğini anlatan meslek erbabı da yetişmiş. Markaların nasıl cool olacağının sırlarını öğretiyormuş.

İnternette nasıl cool olunur köşeleri de yer alıyor. 10, 20, 40 maddede cool olmanın yolları anlatıliyor. İnsanlar nasıl cool olunur diye soruyorlar. Cool olmak önemli çünkü. Aşağıda cool olmanın bazı koşulları sayılmış:

Mesajlaşırken emoji kulanmamak / gelen mesajlara geç cevap vermek / Sevgiliyle buluşurken süslenip püslenmemek / Salaş ve umursamaz olmak / Sürekli meşgul görünmemek / Yoğunluktan şikayet etmemek / cool görünmeye kafayı takmamak / cool olmak için cool görünmeye çabalamamak.

Son olarak cool sözcüğünün ne kadar yayıldığına bakmak gerekir. Bu sözcük gazete diliyle mi sınırlı yoksa geniş kitlelere yayıldı mı? $\mathrm{Ne}$ yazık ki sözcüğün geniş kitlelere yayıldığını söylemek durumundayız. Cool artık herkes tarafından özenilerek kullanılıyor. Sözcüğün yayılımını anlatmak için reklamları örnek göstermek yerinde olur. Cool sözcüğü televizyon reklamları aracılığıyla halka kadar inmiştir. Reklamlar milyonlarca kişi tarafindan izlenmektedir. Bir süt, bir dondurma ve bir bisküvi firması içinde defalarca geçen coollu reklamlar yaparak sözcüğü zihinlere kazımışlardır. Ünlü bir süt markası ürettiği ayran için cool olup olmamaya dayalı üç ayrı reklam filmi çekmiş ve yayımlamıştır. 
Cool sözcüğü Türk diline bir ihtiyaçtan değil özentiden dolayı girdi.Türkçede cool sözcüğü karşılığında kullanılacak pek çok sözcük var. Cool yerine soğuk, serin, sakin, durgun, donuk, soğukkanli; serinlik, sükunet; serinlemek, soğutmak, teskin etmek sözcülerini ve sözcük gruplarını kullanabiliriz. Birden çok sözcük varken hepsi için coolu kullanmak dili yoksullaştırmaz $\mathrm{m}$ ?

Ayrıca coolun yan anlamlarını karşılayan büyülü, havalı, çekici, cazip, cazibeli, karizmatik, özgüvenli, stil sahibi, tarz, burnu büyük, kibirli, ukala, pişkin, şık, moda, albenili, dingin, durgun, donuk, geniş, endişesiz, paniksiz, ciddi gibi pek çok sözcük var. Burada biz ikisi söz grubu yirmi biri yalın yirmi üç sözcük belirledik. Türkçede coolu karşılayan yirmi üç sözcük varken bir tek sözcüğe indirgiyoruz. Bu dili varsıllaştırmak değil yoksullaştırmaktır. Dille ilgilenenlerin bildiği ve inandığı şey yazarların dili işleyen ve geliştiren kişiler olmasıdır. Cool örneğinde ise geriye gidiş söz konusudur.

Biz yazarlarımıza, gazeteci-yazarlarımıza sorumluluklarını hatırlatmak isteriz. Popüler tutumlarla lütfen dilimizi yabancılaştırmasınlar, yozlaştırmasınlar. Ana dilleri lehine çaba göstersinler. Reklam yazarlarına da aynı sözlerle sesleniyoruz. Onların özendirmede güçleri daha fazla ve bunun yollarını da iyi biliyorlar. Onlar da yabancı sözcüklerle halkı etkilemeye çalışmasınlar. Yazarların okuyucusu sinılıdır, ama reklamcılar, televizyon aracılığıyla milyonlara sesleniyor ve onları etkiliyorlar. Yabancı sözcüklerin değil Türkçe olanların yanında yer almaları ana dili sevdalılarının dileği ve umududur.

\section{KAYNAKÇA}

Güncel Türkçe Sözlük. Türk Dil Kurumu Sözlükleri. https://sozluk.gov.tr/ (Erişim Tarihi: 21.03.2021).

Redhouse (1986). English - Türkish Dictionary. İstanbul.

Uzuner, B. (2013). Su. İstanbul: Everest Yayınları. 